\title{
Investigation 8th Grade Students Secondary School Cognitive Structure about Principles of Ataturk through Word Association Test
}

\author{
Ozkan Akman ${ }^{1}$, Erol Koçoğlu \\ ${ }^{1}$ Department of Social Studies, Gaziantep University, Turkey \\ ${ }^{2}$ Department of Social Studies, Inonu University, Turkey \\ Correspondence: Ozkan Akman, Department of Social Studies, Gaziantep University, Turkey.
}

Received: June 27, 2016

doi:10.11114/jets.v4i11.1696

Accepted: July 18, $2016 \quad$ Online Published: October 17, 2016

URL: http://dx.doi.org/10.11114/jets.v4i11.1696

\begin{abstract}
The purpose of this study is to present the connections between the concepts in perception and cognitive structures of secondary school 8th grade students for principles of Ataturk. Word association test is used in data collection. The number of the total participants in this research is 190. A frequency table is formed for the data obtained in the research, then obtained frequency data has been analyzed by using inspiration 8.00 program. According to the results of the research; it has been observed that the most repeated words are irreligion, fascism, racism, festival, contemporaneousness, Islam and religion. The data obtained in the result part of the research has been compared with other studies. As the result, it has been determined that the word association test is an measurement tool which is appropriate for learning how the students attribute mean to the concepts.
\end{abstract}

Keywords: word association test, Ataturk's principles, Kemalism

\section{Introduction}

According to Turkish Education Board, History of Revolution and Kemalism course was taught in all schools from earlier grades to college levels and accepted one of most important course in social studies education with its special goals and contents related to Turkish revolution and Atatürk. Over all of its goals “to teach Atatürk's vision, the mission of Turkish republic and importance and dedication for the freedom are main concerns in the course. It is generally accepted that founding a new republic after an empire and long term wars had its own conditions as well as difficulties. In this context economical, social and political obstacles went on after foundation of the state. To raise awareness and patriotism; give information about the republic and ideas of Ataturk are the main goals of the course.

In recent years, the increase in the effect of constructivist learning in education and the deficiency of traditional methods in conceptual change and understanding, cause the occurrence of different techniques and strategies. The techniques which helps us to determine whether the intra-concepts relations are sufficient, have gained importance (Bahar et al., 2006). Word association tests have been used in many different purposes in literature. Word association tests have been used for the different learning fields in determining the conceptual changes and concept faults and in presenting the cognitive structures of the students. However, many of these studies are performed in science courses. The studies made in other branches are quite a little (Is1kl1 et al., 2011). Word association test is a data collection technique which is used for determining the conceptual perception of the individuals or groups (Dikmenli, 2010b). It is used for determining whether the intra-conceptual relation and information network is sufficient in the long-term memory (Bahar \& Ozatl1, 2003). This technique can be used not only for understanding whether these concepts are understood correctly but also the persons (Cardak, 2009).

The data collection stage in this technique is take the concepts which a key concept related with any subjects reminds to the students as a reply within a specific period (mostly 30 seconds) "It is assumed that the serial reply given by the student to a key concept from his long term memory, presents the connections between the concepts in cognitive structure and shows the semantic proximity. According to the semantic distance effect, as much as two concepts are close to each other in terms of distance in semantic memory, they have such close relations and the reply given related with these two concepts shall be faster in cognitive research during the reminder (Bahar \& Ozatl1, 2003). 


\subsection{A General Overview to the Relevant Literature}

The occurrence of Ataturk's principles and reforms course, to be seen as a part of history science in 1930s arises from the comparative presentation in international level as a natural part of the citizenship education (Akbaba, 2009; Safran, 1998; Ozucetin \& Nadar, 2010). Therefore, it is important for students to give better meaning to the History of Revolution and Kemalism subjects and to present the cognitive pre-learning in this respect as well as the teaching of the subject.

The expectation of strategies and questions developed for the solution of the questions, approaches in problem solving and comprehending the questions in different measuring techniques, show differences (Ates \& Karacam, 2008; Ercan et al., 2010). Therefore, it is important to determine how much the students understand the History of Revolution and Kemalism as conceptual and are successful in providing the conceptual change. Together with the adaptation of structural education comprehension in education since 2005, alternative evaluation approaches are started to be used as well as the traditional measurement, evaluation approaches. These alternative techniques started to gain importance for presenting the cognitive structures of the students (Bahar et al., 2006). Therefore some strategies have been developed for providing and measuring the conceptual understanding and change. Bahar (2003) has listed these strategies as follows; word association, structured grid, branched tree, concept maps, conceptual alteration texts, analogy, estimation-observation and explanation.

Johnstone et al., (1985) expresses the implementation of word association test as follows: (i) the researcher shall firstly prepare the guidance questions. (ii) the prepared guidance questions are distributed to the students. (iii) the student selects the sections required for answering the guidance questions. (iv) The student performs this for each question therefore he connects with the teacher through the structure applied in random guidance- it is named as structural communication. The content of these boxes may be words, expressions, pictures, equations, numbers, explanations, formulas and more. When this type of data is given to the students, they do not know how much boxes are needed for answering the questions and they must consider the content of each box and they must decide the boxes and which box is the part of the reply given to the asked question. Thusi word association test expresses that it is rational to say that the skill of selecting the relevant one from the irrelevant one, is tested (Bahar \& Hansell, 2000).

The studies made with the word association test, are generally related with the science courses. Many searches have been made related with the science courses until today (Shavelson, 1972; Shavelson, 1974; Preece, 1978; Kempa \& Nicholls, 1983; Johnstone \& Moynihan, 1985; Cardellini \& Bahar, 2000; Cardak, 2009; Dikmenli, 2010a; Ercan et al., 2010; Bahar et al., 1999; Cachapuz \& Maskill, 1987; Carrie, 1984; Gussarsky \& Gorodetsky, 1988; Witkin \& Goodenough, 1981). By using word association test, it is applied to nearly all psychological science branches like social psychology (Rudman et al., 1999; Hofmann et al., 2005), personality psychology (Asendorpfetal, 2002), clinical psychology (Teachman et al., 2001), consumer psychology (Maison et al., 2001), health psychology (Wiers et al., 2002), gerontology (Hummert et al., 2002), and neuropsychology (Phelps et al., 2000). There is even a little study in social field. One of these studies is the study made by Bahar \& Kılıc (2001). Bahar \& Kılıç (2001) has searched the cognitive connections between Ataturk' principles with the word association test which is applied to the officer candidates. As the result of the research, it is determined that the opinion system forming Kemalism is perceived by the participant in correct form however they assign different meanings to some principles.

Bahar et al., (1999) has applied word association test on university 1.st grade biology students after the lecturing on genetic field. Although the students produce many replies to the key concepts, it is seen that they cannot see these concepts as interpenetration and a relevant weblike structure. As the result of the research, it has been observed that the teacher has used multiple choice (four choices) test in the exams, most of the questions do not examined the relations between the concepts and on the contrary the concepts which are separately in islet form in cognitive structure.

Another study of Bahar \& Ozatlı (2003), is made for searching the relevant cognitive structure and main components of the creatures from Biology I subjects. The study has been on 60 students of Balıkesir Girls Technique- Anatolian Girls Vocational and Girls Vocational High School by using word association test. Pre-test, final test word association test is applied to the students before and after lecturing, a concept map is prepared by using a frequency table which is issued from the replies of the student given to selected key concept. The results of the research have shown that the prior knowledge of the students has spread to a wide area which is not so connected with the subject, more scientific and more replies are given to final tests rather than the pre-tests. The concept tests have shown that the students do not perceive the relation between concept in complete network form. The importance of the results of the research in terms of biology education and how the word association test is used as an education tool is examined.

Isıklı et al., (2011) has made a study for presenting the cognitive structure of class teacher candidates related with Ataturk's principles through word association test. It has been observed that the teacher candidates mostly use the concepts like Ataturk, public, justice and freedom. Besides, it has been observed that the teacher candidates have some 
concept failures related with the Nationalism and State Socialism in both their sentences and concept network. As the result of the research, it is thought that the word association test is an alternative measurement tool to be used more frequently in education environment.

\subsection{The Purpose of the Research}

The purpose of this research is to determine the cognitive structures of secondary school 8th grade students in Ataturk's principles by using word association test.

\section{Method}

\subsection{The Pattern of the Research}

The phenomenology study pattern among qualitative study techniques is used in this research. The phenomenology pattern study is research method that studies a phenomenon within a natural real life and studies the phenomenon as multi-directional, systemic and profoundly (Ekiz, 2006; Karasar, 2004; Cohen \& Manion, 1997; Patton, 1990; Verma \& Mallick, 1999). The studies made in this pattern should be detailed as much as possible and should be related with the data of the participants (Kus, 2003).

\subsection{Participants}

The participants of this research are 8th grade students at Namık Kemal Secondary school in Karatay district of Konya. The total number of students participating this research is 204.14 of these students are not evaluated for not having data appropriate to the purpose. Therefore the number of the examined students, is $190.100(55 \%)$ of the examined students are male and $90(45 \%)$ of them are females.

\subsection{Instruments}

This study presents the concepts in cognitive structures of the students for six principles of Ataturk and concept failures of students for these principles by using word association test. There are six principles and these principles are in relation with each other. It is natural for the students to attribute meaning to these concepts by using congenial words accordingly, the guidance principles are;

\subsubsection{Laicism Principles}

To bring the religion phenomenon to a comprehensive level, to recognize the religion and conscience freedom of the state by bringing the religious works within a regular order. Shortly, secularism is to keep the religious works and state works as separate. It expresses the worshipping freedom of everyone. The students are expected to attribute concepts to these guidance concepts within the frame of freedom and religion.

\subsubsection{Republicanism Principle}

The republicanism is a management type which the national sovereignty is dominant. The republicanism principle of Ataturk is one of the main specifications of new Turkish state, and it is management by the public in simplest form. In other words, it is the freedom of the state within the boundaries of a country to select the persons who are believed to provide the welfare and security.

\subsubsection{Statism Principles}

It expresses the control of the economy by the state on behalf of our nations when needed with the condition to take the special intervention and activities of individuals as the basis. The state socialism means the actualization of the works required for economical and social development.

\subsubsection{Nationalism Principles}

It expresses the performances of Turkish citizens for their own existence and happiness and the respect to the nation unity and integrity shown by other countries' citizens. The nationalism of Ataturk contains a major tolerance. It desires not only the continuity of its national existence and unity but also of our nations.

\subsubsection{Populism Principles}

In a country governed with republic, to guard the benefit of the public in using the state opportunities in political development, management. Populism Principle is based on the equality of whole individual of the nation before law and in Turkish individual, family and class dominancy in Turkish nation, shall not exist.

\subsubsection{Reformism Principles}

It is to make the innovation required by mind, science and era in accordance with the needs of the society. It is to regulate works which have more damages than the old and invalid benefits. 


\subsection{Data Collection Tools}

As the data collection data, word association test is used in the research. It is aimed to collect detailed data related with the principles of Ataturk from the participants. These concepts; laicism, republicanism, statism, nationalism, populism, reformism. The test is prepared by writing each key concepts as to be side by side and top and bottom for 10 times. The repetition of the key concepts till the end of each page, prevents the chain reply risk. If the student does not turn the key concept in written concept shall be written related with the written concept shall be written. This shall cause the test to be beyond its purpose (Bahar \& Ozatl1, 2003). It is determined that to give 45 seconds to the students for each concept shall be the most appropriate time zone by evaluating the previous studies (Bahar \& Kılıç, 2001; Bahar \& Ozatli, 2003; Çardak, 2009; Dikmenli, 2010a; Dikmenli, 2010b; Ercan et al., 2010; Isıklı et al., 2011; Aydın \& Tasar, 2010; Koseoğlu \& Bayır, 2011; Nakiboglu, 2008; Ozatlı \& Bahar, 2010; Timur \& Taşar, 2011; Torkar \& Bajd, 2006; Kurt \& Ekici, 2013). Test is applied to the students by making the essential explanations and applying samples.

\subsection{Analysis of the Data}

The reply words given to the key concepts are examined in detail for analyzing the word association test results. The data has been analyzed according to content analyzed method. In content analyses, the main purpose is to reach the concept and relations that may explain the data (Ylldirım \& Simsek, 2006). The data obtained from the independence word association test, are analyzed by using the word number, reply number and semantic relation technique (Atasoy, 2004). The words which are replied with the same meaning, are classified under the most repeated words. The irrelevant words and words with no relation with other words and the words which are repeated for 1-2-3 times, are not evaluated. The words are categorized by using semantic relation criteria and the frequency of the words is calculated (Daskolia et al., 2006; Kostova \& Radoynovska, 2008; Kostova \& Radoynovska, 2010). The frequency table is shown in Appendix A. Then the concept network map of the obtained data is issued by using İnspration 8 package program. In concept network formation process, the cut point technique which is presented by Bahar et al., (1999), is used. According to Bahar et al., (1999), in cut point technique, a value below of the the most given reply word for any key concept in frequency table, is determined as the cut point. The concepts above this value forms the first part of the concept network. Then the cut point is pulled down with specific intervals and the process continues till all key words are seen in the concept network. The data is commented by evaluating the new formed words and associations between the concepts with the help of the concept networks which are formed by using the cut point in this research. The concept networks are formed in data analysis by using this technique according to these cutting points: 180-150, 149-120, 119-90, 89-60, 59-30, 29-3. While the obtained cut points are shown in figure 1, the arrows coming from each guidance word, are expressed with different colors. The republicanism is expressed with black, the laicism concept with blue, nationalism with green, populism with dark blue, the statism with orange and reformism with red. Besides the thickness of the arrows forming the cut points, become thin from the most repeated to the less.

\section{Findings}

In this sections, the data obtained from the applied word association test, is analyzed. The findings and comments are presented with the concept map. 190 persons from 8th grade students have participated to the researched. The students are applied word association test which forms from the key concepts like laicism, republicanism, statism, nationalism, populism and reformism. The collected data is evaluated in terms of reply word number, their varieties and their relation with each other and the concept network is formed according to the obtained result. Concept networks show the occurred relations of key concepts according to the cut points (Figure 1). 


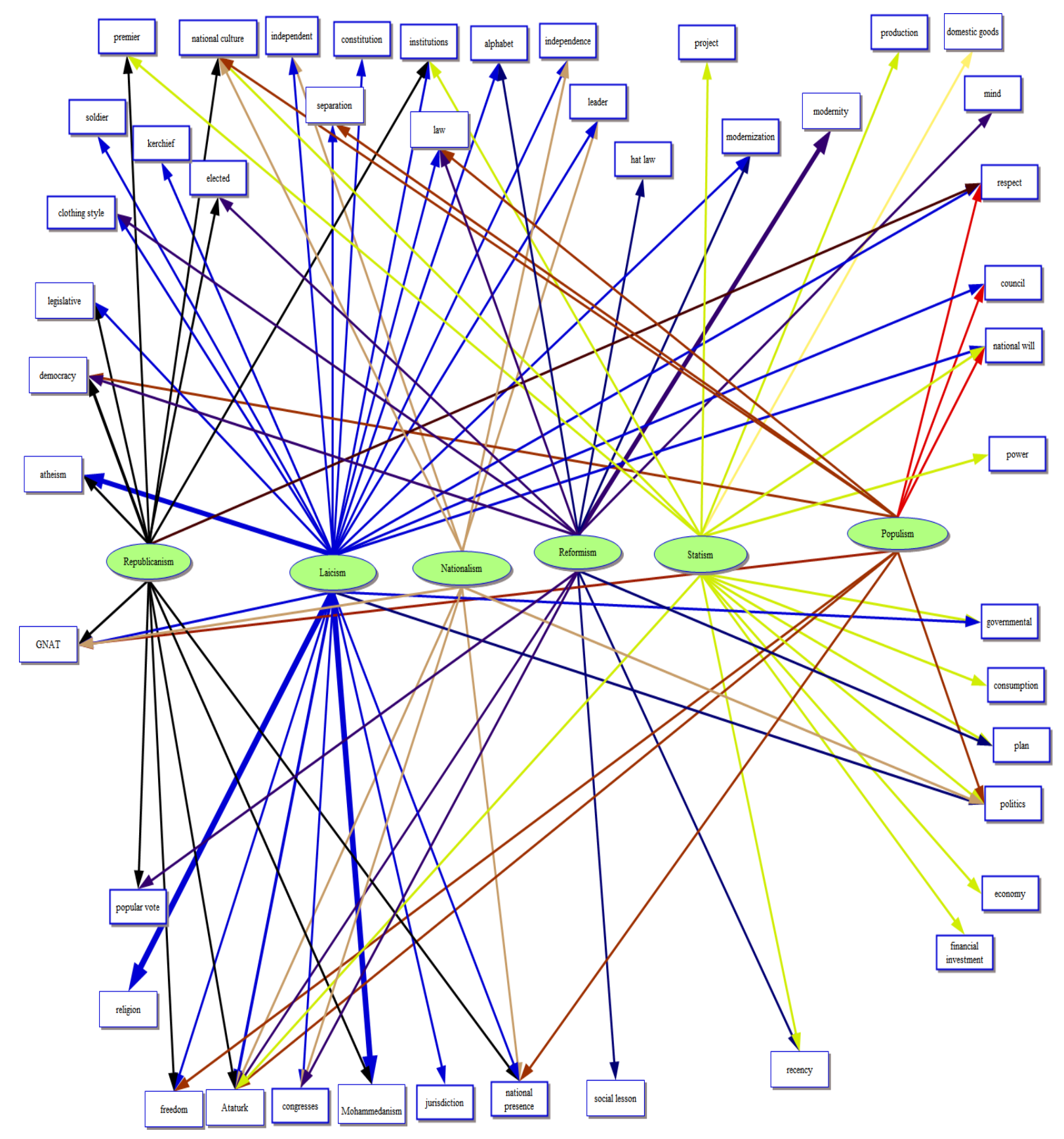

Figure 1. Concept network which forms according to the cut points

Cut point for 180-150: The thick blue arrows which occur in laicism key concept is associated with the Islam and religious words. There is not an association with the other key concepts. At the same time their relations are far from each other.

Cut point for 149-120: The blue arrow which occurs with the laicism concept is thinner and is associated with the irreligion. The reformism concept is associated with the dark blue arrow and modernity concept. However their relation is still disconnected.

Cut point for 119-90: The black arrow occurs with the republicanism, is associated with democracy, management and holiday words. The green arrow occurring with the nationalism concept is associated with the racialism, fascism and French revolution. However their relation is still disconnected.

Cut point for 89-60: the black arrow occurring with the republicanism is associated with TBMM, deputies, legislation and Ataturk words. The yellow arrow occurring with statism word, is associated with Turkish citizen, red arrow occurring with populism, is associated with the president of republic. The dark blue arrow occurring with the reformism 
is associated with social course, modernization and innovation. The blue arrow occurring with the laicism is associated with Ataturk and freedom words. However their relation is still disconnected.

Cut point for 59-30: The blue arrow occurring with the laicism is associated with separation and law words. The black arrow occurring with the republicanism is associated with president of republic, Turkish nation, national struggle, independence march, popular opinion, selection, parties, parliament and national presence words. The yellow arrow occurring with statism word is associated with investment of money, production, state, plan, economy, consumption and innovation words. The pink arrow occurring with nationalism word is associated with Ataturk, flag, independence, independence march and leader words. The red arrow occurring with populism is associated with democracy, parliament, management, national struggle, freedom, TBMM, equality and Ataturk words. The purple arrow occurring with reformism is associated with hat law, Ataturk and mind words.

When the relations between the concepts in this cut point, are considered, the republicanism concept and nationalism concept is associated with the national march. The republicanism concept and populism concept is associated with the parliament. The nationalism concept and republicanism concept is associated with the national asset. The statism, populism and reformism is associated with Ataturk word.

Cut point for 29-3: in this interval, the relations become more complex. The blue arrow occurring with the laicism is associated with modernism, TBMM, respect, soldier, judicial, scarves, constitutional law, legislation, law, leader, state, policy, institution, separation and clothing styles. The black arrow occurring with the republicanism is associated with freedom, leader, Ankara, congress, judiciary, national will, freedom, history, national culture, independency, country, policy and life. The yellow arrow occurring with statism word, is associated with project, Ataturk, policy, institution and power words. The pink arrow occurring with nationalism word, is associated with freedom, TBMM, country, congress, Turkey, culture, national struggle, history, leader, solidarity, equality, fight, politics, management, geography and living. The red arrow occurring with populism, is associated with respect, policy, culture, party, nation, public, separation, judicial, peace, national culture, national assets, national struggle, country and benefit struggle. The purple arrow occurring with reformism is associated with alphabet, development, law, congress, reform, selection, plan and referendum.

When the relations between the concepts in this cut point are considered, the concept of laicism and nationalism words Parliament and the judiciary; secularism, republicanism and respect the word populism; the concept of laicism and reformism word law; the concept of secularism and republicanism and independence leader words; the whole concept of the word politics; the secular and statist concept of corporate word, with populism and to leave the concept of laicism words, the laicism and reformism concept of clothing style word; republicanism, nationalism, and with the reformism concept convention words; with republicanism and date with the concepts of nationalism and a fight words, republicanism and national culture of populism concept, human, and facing a fight with words; republicanism, nationalism and populism with the concepts of homeland and carry the words; words that are associated with the national struggle with the concept of nationalism and populism were found to unite in the same common denominator.

\section{Result, Discussion and Conclusions}

In this study, the secondary school 8th grade students are requested to reproduce words related with the concepts forming Ataturk's principles with word association tests and how the words associate with Ataturk' principles and how can they associate with words; an evaluation is made by considering the number of reproduced words and their relations with each other.

With word association test many national (Bahar \& Kılıc, 2001; Bahar \& Ozatl1, 2003; Cardak, 2009; Dikmenli, 2010a; Dikmenli, 2010b; Ercan et al., 2010; Isıklı et al., 2011; Aydın \& Taşar, 2010; Köseoğlu \& Bayır, 2011; Nakiboglu, 2008; Ozatlı \& Bahar, 2010; Timur \& Taşar, 2011; Torkar \& Bajd, 2006; Kurt \& Ekici, 2013) and international (Johnstone, 1998; Shavelson, 1972; Shavelson, 1974; Preece, 1978; Kempa \& Nicholls, 1983; Johnstone \& Moynihan, 1985; Cachapuz \& Maskill, 1987; Carrie, 1984; Gussarsky \& Gorodetsky, 1988; Witkin \& Goodenough, 1981) studies were made. Some parts of these studies are made in science and technology field and some part is made in social fields. However the studies made in social fields are less. It is determined that the studies are mainly made in science field.

When the meaning attribution of secondary school 8th grade students to the concepts related with Ataturk principles are considered, the most repeated word between cut points 180-150, the most repeated word with the laicism is Mohammedanism and religion words with the thickest arrow. Basgil (2007) identifies the laicism as not intervening to the worshipping forms and internal order of current religions and sects. In other words, it is to see the people free for living their religion. However in cut point 149-120, the students have seen the laicism concept as irreligion. This is a concept error. When the students give wrong decisions caused by the instinct and opinions of environment, the concept error occurred. It is possible to identify the concept error as the important difference between a concept of a person and the commonly agreed scientific meaning (Marioni, 1989; Tery et al., 1985; Riche, 2000; Stepans, 1996). In addition to 
this, the students have associated the laicism concept with the words like Ataturk, liberty, separation, legal, modernization, clothing style, constitution, government, politics and independence. Kemalism has formed of six main principles. However, while these six principles draw the frame of the Kemalist idea, there are supplemental principles that fill in this frame. The supplemental principles are a part of idea systematic which is a guide for commenting each of six main principles. This systematic is the value integrity which expresses the personality specification of Ataturk. Therefore, it is natural to have this word in conscious of the students. It is observed that Isikl et al., (2011) has the same results in his study but in his study, there are much more concept error in the words associated with the secularism concept. Its reason is the different target group.

When we consider the replies of the students given for the nationalism, it is observed that the nationalism is associated with fascism, the French revolution, racism, the Turkish public, national presence and Ataturk . It is seen that the students have associated the word with similar concepts in the study made by Iskklı et al., (2011). It is meaningful that the common point is the association of nationalism as the racism. The group with the age average of 14 has associated with the same word with the group with the age average of 22 . This arises from the different meanings attributed to the concepts since the elementary school. The nationalism has brought a nationalism approach based on the scientific methods that may be accepted by everyone. The nationalism is a defense mechanism which arises from our complexities, wannabe, a political ideology that may be assimilate to Fascism, Nazism, a wannabe that may be connected to French depressions. The nationalism is a society reality which is a continuity claim in history stage (Balc1, 2011) The racism is a point of view which see the nations as the structures that exist since ancient eras rather than being a national theory (Aydın, 1993).

The republicanism concept is associated with the concepts like feast, manage, democracy, flag, Parliament deputies, legislative, Ataturk, the Turkish people, national struggle, independence anthem, election. Bahar \& Kılıç (2001) has associated republicanism with the freedom word. Isıklı et al., (2011) has associated with the justice and equality.

In this study, the students have associated the state socialism principle with the words like domestic goods, financial investment, manufacturing, government, plan, economy and consumption. Isıkl et al., (2011). As related with the state socialism, the sentences emphasizing the state management draw attention Bahar \& K1lic (2001) has associated this word like the worlds related with the similar economy.

The students have associated the concept of populism with the words like democracy, solidarity, president, parliament, manage, national will, freedom, Parliament, Ataturk, equality, respect and politics. Bahar \& Kilic (2001) has associated the populism with the words like society and Isıklı et al., (2011) has associated the populism with the words like unity and equality.

It is seen that the reformism concept is association with modernity, social studies, innovation, modernization, hat law, reason, Ataturk, alphabet, clothing, development, laws, conventions, laws, reforms and democracy. Bahar \& K1lıc (2001) and Isıklı et al. (2011) has associated the reformism concept with the innovation word.

Sometimes it is not enough to explain Ataturk's principles with six concepts. As known, Ataturk has supplementary principles like national independence, national sovereignty, modernity, science, human love, peace at home peace in the world, rationality.

The students see the common point of all concepts as Ataturk. The reason is; Ataturk has mentioned in his many speeches that he has commended the republic to the youth not to the government. The main reasons; the youth is open to the innovation, they are not afraid of changes and they hope a better future. Each social movement tends to institutionalism, compliance. However it is not considered for these youth movements. Because, the youth is a power that may not be stereotype. For all the reasons, the youth is idealist (Cecen, 1981).

Through the word association test used in data collection tool, this research is made for comprehending the concepts and presenting the meanings attributed to these concepts. It has provided us to see the faults and errors in the meanings given to the concepts. Essential studies are made for understanding the concepts in education environment by considering the relation of the words like irreligion, fascism and racism to the concepts. It must be taught in the Revolution History and Kemalism course that the nationalism is not racism and the secularism is not irreligion by considering these error or associations. We can say that the word association test is an efficient measurement and evaluation technique in measurement of relations between the concept. Besides, it is thought that this test may be used in teaching and understanding the different concepts of social studies and citizenship education.

\section{References}

Akbaba, B. (2009). Atatürk İlkeleri ve İnkılâp Tarihi Dersinin Öğretimine Yönelik Bir Durum Değerlendirmesi (Gazi Üniversitesi Örneği). Türkiye Sosyal Araştırmalar Dergisi, 13(1), 29-52.

Asendorpf, J. B., Banse, R., \& Mücke, D. (2002). Double dissociation between implicit and explicit personality 
self-concept: the case of shy behavior. Journal of personality and social psychology, 83(2), 380 . http://dx.doi.org/10.1037/0022-3514.83.2.380

Atasoy, B. (2004). Fen öğrenimi ve ögrretimi. Asil Yayın Dă̆ııım.

Ateş, S., \& Karaçam, S. (2008). Cinsiyetin Farklı Ölçme Teknikleri Kullanılarak Ölçülen Hareket ve Hareket Yasaları Konularındaki Kavramsal Bilgi Düzeyine Etkisi, GÜ, Gazi Eğitim Fakültesi Dergisi, 28(1) 39-59. http://dx.doi.org/10.11616/abantsbe.155

Aydin, F., \& Taşar, F. (2010). An Investıgatıon of Pre-Servıce Scıence Teachers'cognıtıve Structures and Ideas About the Nature of Technology. Ahi Evran Üniversitesi Kırşehir Eğitim Fakültesi Dergisi, 11(4).

Bahar, M., \& Kılıç, F. (2001). Kelime İletişim Testi Yöntemi İle Atatürk ilkeleri Arasındaki Kavramsal Bağların Araştırılması (Bildiri). IX. Eğitim Bilimleri Kongresi, Bolu.

Bahar, M., \& Özatlı, S. (2003). Kelime İletişim Testi Yöntemi ile Lise 1. Sınıf Öğrencilerinin Canlıların Temel Bileşenleri Konusundaki Bilişsel Yapılarının Araştıılması. Balıkesir Üniversitesi Fen Bilimleri Enstitüsü Dergisi, $5(2), 75-85$.

Bahar, M. (2006). Geleneksel-Alternatif Olcme Degerlendirme Teknikleri Ogretmen El Kitabi. Pegem A Yayincilik, Ankara.

Bahar, M., \& Hansell, M. H. (2000). The relationship between some psychological factors and their effect on the performance of grid questions and word association tests. Educational Psychology, 20(3), 349-364. http://dx.doi.org/10.1080/713663739

Bahar, M., Johnstone, A. H., \& Sutcliffe, R. G. (1999). Investigation of students' cognitive structure in elementary genetics through word association tests. Journal of Biological Education,33(3), 134-141. http://dx.doi.org/10.1080/00219266.1999.9655653

Bahar, M., Nartgun, Z., Durmus, S., \& Bicak, B. (2006). Traditional and alternative assessment and evaluation of teachers' manual. Ankara: Pegem A Publisher.

Balcı, E. (2011). Türkiye'deki Milliyetçilik Söylemleriyle Kıyaslamalı Olarak Erol Güngör'ün Sosyolojik Milliyetçilik Anlayışı. Sosyoloji Araştırmaları Dergisi, 14(1).

Başgil Ali Fuat, Din ve Laiklik, Yağmur Yayınları, İstanbul 1998. http://dx.doi.org/10.1163/1573-3912_ei3_com_24308

Cachapuz, A. F. C., \& Maskill, R. (1987). Detecting changes with learning in the organization of knowledge: Use of word association tests to follow the learning of collision theory. International Journal of Science Education, 9(4), 491-504. http://dx.doi.org/10.1080/0950069870090407

Cardellini, L., \& Bahar, M. (2000). Monitoring the learning of chemistry through word association tests. Australian Chemistry Resource Book, 19, 59-69.

Carrie, T. G. (1984). Combıned Experımental/Analytı Cal Modelıng Usıng Component Mode Synthesıs. http://dx.doi.org/10.2514/6.1984-941

Cohen, L., Manion, L., \& Morrison, K. (1997). Methodology of educational research. Athens: Expression. http://dx.doi.org/10.4324/9780203282632

Cardak, O. (2009). The determination of the knowledge level of science students on energy flow through a word association test. Energy Education Science and Technology, 1(1), 139-155.

Cecen, A. (1981). Atatürk ve İdeoloji, Türk Dili, TDK Yayını, 359, 29

Daskolia, M., Flogaitis, E., \& Papageorgiou, E. (2006). Kindergarten teachers' conceptual framework on the ozone layer depletion. Exploring the associative meanings of a global environmental issue. Journal of Science Education and Technology, 15(2), 168-178. http://dx.doi.org/10.1007/s10956-006-9004-8

Dikmenli, M. (2010a). Biology studentse conceptual structures regarding global warming. Education Science and Technology, 2(1), 21-38.

Dikmenli, M. (2010b). Biology student teacherse conceptual frameworks regarding biodiversity. Education, 130(3), 479-489.

Ekiz, D. (2006). Öğretmen eğitimi ve öğretimde yaklaşımlar. Nobel Yayın Dağıtım.

Ercan, F., Taşdere, A., \& Ercan, N. (2010). Kelime ilişkilendirme testi aracılığıyla bilişsel yapının ve kavramsal değişimin gözlenmesi. Türk Fen Eğitimi Dergisi, 7(2), 136-154.

Gussarsky, E., \& Gorodetsky, M. (1988). On the chemical equilibrium concept: Constrained word associations and 
conception. Journal of Research in Science Teaching, 25(5), 319-333. http://dx.doi.org/10.1002/tea.3660250502

Hofmann, W., Gawronski, B., Gschwendner, T., Le, H., \& Schmitt, M. (2005). A meta-analysis on the correlation between the Implicit Association Test and explicit self-report measures. Personality and Social Psychology Bulletin, 31(10), 1369-1385. http://dx.doi.org/10.1177/0146167205275613

Hummert, M. L., Garstka, T. A., O'Brien, L. T., Greenwald, A. G., \& Mellott, D. S. (2002). Using the implicit association test to measure age differences in implicit social cognitions. Psychology and aging, 17(3), 482. http://dx.doi.org/10.1037/0882-7974.17.3.482

Isıklı, M., Taşdere, A., \& Göz, N. L. (2011). Kelime İlişkilendirme Testi Aracıllğıyla Öğretmen Adaylarının Atatürk ilkelerine Yönelik Bilişsel Yapılarının İncelenmesi. Uşak Üniversitesi Sosyal Bilimler Dergisi, 4(1), 50-72. http://dx.doi.org/10.12780/uusbd82

Johnstone, A. H., \& Moynihan, T. F. (1985). The relationship between performance in word association tests and achievement in chemistry. European Journal of Science Education, 7, 57-66. http://dx.doi.org/10.1080/0140528850070106

Karasar, N. (2004). Bilimsel araştırma yöntemi: kavramlar, ilkeler, teknikler. Nobel Yayın Dağııım.

Kempa, R. F., \& Nicholls, C. E. (1983). Problem - solving ability and cognitive structure - an exploratory investigation. European Journal of Science Education,5(2), 171-184. http://dx.doi.org/10.1080/0140528830050205

Koseoglu, F., \& Bayir, E. (2011). Examining cognitive structures of chemistry teacher candidates about gravimetric analysis through word association test method. Trakya University Educational Faculty Journal, 1(1), 107-125.

Kostova, Z., \& Radoynovska, B. (2008). Word association test for studying conceptual structures of teachers and students. Bulgarian Journal of Science and Education Policy, 2(2), 209-231.

Kostova, Z., \& Radoynovska, B. (2010). Motıvatıng Students'learnıng Using Word Association Test And Concept Maps. Bulgarian Journal of Science \& Education Policy, 4(1).

Kurt, H., \& Ekici, G. (2013). Determining cognitive structures and alternative conceptions on the concept of reproduction (The case of pre-service biology teachers). Creative Education, 4(09), 572. http://dx.doi.org/10.4236/ce.2013.49083

Kus, E. (2003). Nicel-nitel araştırma teknikleri. Ankara: Anı Yayıncılık.

Maison, D., Greenwald, A. G., \& Bruin, R. (2001). The Implicit Association Test as a measure of implicit consumer attitudes. http://dx.doi.org/10.1207/s15327663jcp1404_9

Marioni, C. (1989). Aspects of Students' Understanding in Classroom Settings (Age 10-17): Case Study on Motion and Inertia. Physics Education, 24(5), 273-277. http://dx.doi.org/10.1088/0031-9120/24/5/307

Nakiboglu, C. (2008). Using word associations for assessing non major science students' knowledge structure before and after general chemistry instruction: the case of atomic structure. Chemistry Education Research and Practice, 9(4), 309-322. http://dx.doi.org/10.1039/b818466f

Ozucetin, Y., \& Nadar, S. (2010). Atatürk İlkeleri ve İnkılap Tarihi Dersinin Üniversiteler Düzeyinde Okutulmaya Başlanması ve Gelinen Süreç. The Journal of International Social Research, 3(11), 474.

Patton, M. Q. (1990) Qualitative Evaluation and Research Methods. Newbury Park, CA: Sage. http://dx.doi.org/10.1002/nur.4770140111

Phelps, E. A., O’Connor, K. J., Cunningham, W. A., Funayama, E. S., Gatenby, J. C., Gore, J. C., et al. (2000). Performance on indirect measures of race evaluation predicts amygdala activation. Journal of Cognitive Neuroscience, 12, 729-738. http://dx.doi.org/10.1162/089892900562552

Preece, P. F. (1978). Exploration of semantic space: Review of research on the organization of scientific concepts in semantic memory. Science education, 62(4), 547-562. http://dx.doi.org/10.1002/sce.3730620415

Riche, R. D. (2000). Strategies for Assisting Students Overcome Their Misconceptions in High School Physics. Memorial University of Newfoundland Education. 6390

Rudman, L. A., Greenwald, A. G., Mellott, D. S., \& Schwartz, J. L. (1999). Measuring the automatic components of prejudice: Flexibility and generality of the Implicit Association Test. Social Cognition, 17(4), 437-465. http://dx.doi.org/10.1521/soco.1999.17.4.437

Safran, M. (1998). İnkılâp Tarihi Öğretimine Yaklaşım Sorunları, G.Ü.G.E.F. Dergisi, 18(3), 5-17.

Shavelson, R. J. (1972). Some aspects of the correspondence between content structure and cognitive structure in 
physics instruction. Journal of educational psychology, 63(3), 225. http://dx.doi.org/10.1037/h0032652

Shavelson, R. J. (1974). Methods for examining representations of a subject - matter structure in a student's memory. Journal of Research in Science Teaching, 11(3), 231-249. http://dx.doi.org/10.1002/tea.3660110307

Stepans, J. (1996). Targeting Students' Science Misconceptions: Physical Science Concepts Useing the Conceptual Chance Moldel. Riverview, Fla.: Idea Factory. http://dx.doi.org/10.1126/science.287.5456.1199b

Suavi, A. (1993). Modernleşme ve Milliyetçilik. Gündoğan Yay., Ankara.

Teachman, B. A., Gregg, A. P., \& Woody, S. R. (2001). Implicit associations for fear-relevant stimuli among individuals with snake and spider fears. Journal of abnormal psychology, 110(2), 226. http://dx.doi.org/10.1037/0021-843x.110.2.226

Terry, C., Jones, G., \& Hurford, W. (1985). Children's conceptual understanding of forces and equilibrium. Physics Education, 20, 162-165. http://dx.doi.org/10.1088/0031-9120/20/4/306

Timur, B., \& Taşar, M. F. (2011). Developing pre-service science teachers' cognitive structures about technology: word association test (WAT). Western Anatolia Journal of Educational Sciences, 2011, 131-138.

Torkar, G., \& Bajd, B. (2006). Trainee teachers' ideas about endangered birds.Journal of Biological Education, 41(1), 5-8. http://dx.doi.org/10.1080/00219266.2006.9656049

Verma, G. K., \& Mallick, K. (1999). Researching education: Perspectives and techniques. Psychology Press. http://dx.doi.org/10.4324/9780203980361

Wiers, R. W., Van Woerden, N., Smulders, F. T., \& De Jong, P. J. (2002). Implicit and explicit alcohol-related cognitions in heavy and light drinkers. Journal of abnormal psychology, 111(4), 648. http://dx.doi.org/10.1037/0021-843x.111.4.648

Witkin, H. A., \& Goodenough, D. R. (1981). Cognitive Styles Essence and Origins: Field Dependence and Field Independence Psychological Issues. http://dx.doi.org/10.1002/j.2333-8504.1977.tb01134.X

Yıldırım, A., \& Şimşek, H. (2006). Sosyal Bilimlerde Nitel Araştırma Yöntemleri. Seçkin Yayıncılık. 
Appendix A. Frequency distribution of the concept

\begin{tabular}{|c|c|c|c|c|c|c|}
\hline Replies Words & Laicism & Republicanism & Statism & Nationalism & Populism & Revolution \\
\hline Justice & 1 & 1 & - & - & - & 1 \\
\hline Mind & - & - & 1 & - & - & 36 \\
\hline Alphabet & 2 & 1 & 1 & - & & 28 \\
\hline Constitution & 5 & - & - & - & - & \\
\hline Ankara & 1 & 26 & - & - & - & 2 \\
\hline Treaties & 1 & 1 & - & - & - & 2 \\
\hline Soldier & 19 & 2 & 1 & - & - & - \\
\hline Ataturk & 82 & 58 & 17 & 48 & 29 & 34 \\
\hline Separation & 51 & - & - & - & 18 & - \\
\hline İndependent & 4 & 17 & - & 37 & - & - \\
\hline Minister & 1 & 17 & 3 & 1 & 16 & \\
\hline Peace & 1 & 2 & 1 & - & 17 & - \\
\hline Prime Minister & - & 22 & 3 & - & - & - \\
\hline Headkerchief & 18 & 1 & - & - & 1 & - \\
\hline Flag & - & 78 & 1 & 39 & 1 & - \\
\hline Holiday & 1 & 112 & - & - & - & 1 \\
\hline Geography & - & 2 & - & 4 & - & - \\
\hline President & - & 57 & 2 & 1 & 61 & - \\
\hline Modernity & 1 & 1 & 3 & - & 1 & 120 \\
\hline Remove Fight & - & 5 & 3 & - & 4 & - \\
\hline Solidarity & - & - & 1 & 14 & 43 & - \\
\hline Democracy & 1 & 88 & 2 & 1 & 51 & 3 \\
\hline State & 7 & - & 49 & - & 3 & - \\
\hline Religion & 126 & 4 & - & - & - & \\
\hline Atheism & - & 28 & 1 & - & 17 & 3 \\
\hline Sovereignty & - & - & - & 2 & 2 & - \\
\hline Education & 1 & - & 37 & 1 & 1 & \\
\hline Economy & - & 2 & - & 14 & 59 & - \\
\hline Equality & 1 & 2 & 1 & 101 & - & - \\
\hline Fascism & - & - & 1 & 108 & 2 & - \\
\hline French Revolution & - & - & - & - & 1 & 16 \\
\hline Development & 3 & - & 1 & 2 & 1 & 25 \\
\hline Clothing Style & 1 & 3 & 4 & - & - & 1 \\
\hline Power & 1 & 2 & 2 & 2 & 3 & - \\
\hline Confidence & 1 & 13 & - & - & - & - \\
\hline Our Rights & 1 & - & 2 & 23 & 21 & - \\
\hline People & - & 38 & 1 & - & 1 & 4 \\
\hline Popular Vote & 2 & - & - & - & - & - \\
\hline Life & 31 & 1 & - & - & 17 & - \\
\hline Law & 1 & 27 & - & 25 & - & - \\
\hline İndependence & 1 & - & - & 97 & - & - \\
\hline Racism & - & 1 & - & - & - & - \\
\hline Relationship & - & 2 & - & 1 & - & 12 \\
\hline Revolutions & - & 8 & 1 & 1 & 17 & - \\
\hline Human & - & - & 2 & 2 & 1 & 2 \\
\hline Human Right & 1 & 29 & 1 & 21 & - & - \\
\hline Liberty & - & 41 & 1 & 34 & - & - \\
\hline İndependence Anthem & 11 & - & 2 & 1 & - & 13 \\
\hline Canon & - & 25 & - & 24 & 1 & 13 \\
\hline Congresses & 5 & 6 & 7 & 1 & 2 & - \\
\hline İnstitutions & 1 & 1 & - & 19 & 24 & - \\
\hline Culture & - & - & 1 & 17 & - & - \\
\hline Leader & - & 29 & 2 & - & 36 & - \\
\hline Council & - & - & 1 & - & - & - \\
\hline Manliness & - & 2 & 2 & - & - & - \\
\hline Nationality & - & 61 & - & 1 & 21 & 1 \\
\hline Parliamentarian & - & 23 & 3 & 2 & 34 & - \\
\hline National Will & - & 19 & 3 & 1 & 17 & 1 \\
\hline National Culture & 1 & 45 & - & 19 & 14 & - \\
\hline National Struggle & 1 & 29 & - & 57 & 17 & 2 \\
\hline National Presence & 25 & - & - & 1 & - & 58 \\
\hline Modernization & 180 & 3 & - & 1 & - & - \\
\hline Mohammedanism & 11 & 27 & 2 & 32 & 3 & - \\
\hline Leader & 67 & 21 & 1 & 3 & 30 & - \\
\hline Freedom & - & - & 57 & - & 1 & - \\
\hline
\end{tabular}




\begin{tabular}{|c|c|c|c|c|c|c|}
\hline Financial İnvestment & - & 36 & - & - & 24 & 2 \\
\hline Parties & - & 1 & 47 & - & 2 & 5 \\
\hline Plan & 1 & - & 18 & - & 2 & - \\
\hline Project & - & 1 & - & 14 & 2 & - \\
\hline Battles & 24 & 11 & 1 & - & 27 & - \\
\hline Respect & - & 39 & 1 & 2 & - & 6 \\
\hline Elected & - & - & 1 & 2 & 1 & - \\
\hline Selection & 2 & 1 & - & 1 & 1 & - \\
\hline Love & 1 & - & - & 1 & 2 & 1 \\
\hline To Travel & - & 1 & - & - & - & - \\
\hline System & 6 & 5 & 8 & 6 & 25 & 1 \\
\hline Politics & - & - & 1 & - & - & 68 \\
\hline Social Lesson & - & 2 & 1 & - & - & 41 \\
\hline Hat Law & - & - & 1 & - & - & - \\
\hline Martyr & & 21 & 1 & 19 & 1 & - \\
\hline History & 25 & 63 & 1 & 25 & 30 & - \\
\hline Gnat & - & 20 & 1 & - & 1 & - \\
\hline Society & - & - & 2 & - & - & \\
\hline Ground & - & - & 37 & 1 & - & 1 \\
\hline Consumption & - & 52 & 1 & 85 & 1 & - \\
\hline Turkish People & 2 & - & - & 21 & - & - \\
\hline Turkey & - & - & 52 & 1 & - & - \\
\hline Production & 1 & 12 & - & 25 & 14 & - \\
\hline Homeland & - & 1 & - & 1 & - & - \\
\hline Foreign Language & 19 & 25 & 1 & - & 20 & - \\
\hline Jurisdiction & 12 & 61 & - & 1 & - & - \\
\hline Legislative & - & 5 & - & 4 & 1 & 1 \\
\hline Exist & - & - & 31 & - & - & 62 \\
\hline İnnovation & - & - & 69 & - & - & 1 \\
\hline Domestic Goods & - & 91 & - & 13 & 35 & 1 \\
\hline Govern & 1 & 88 & 1 & 8 & 25 & 1 \\
\hline
\end{tabular}

\section{$(c c)$ EY}

This work is licensed under a Creative Commons Attribution 3.0 License. 